\title{
Interpretation of the Heroine's Emotional Reconstruction in The Ghost Train
}

\author{
$\mathrm{Xian} \mathrm{Wu}^{1}$ \\ ${ }^{1}$ Guangdong University of Science and Technology, Dongguan, China \\ Correspondence: Xian Wu, Guangdong University of Science and Technology, Dongguan 523083, Guangdong, \\ China. E-mail: 876550713@qq.com
}

\author{
Received: April 20, 2021 Accepted: May 26, 2021 Online Published: May 30, 2021 \\ doi:10.5539/ells.v11n2p85 URL: https://doi.org/10.5539/ells.v11n2p85
}

\begin{abstract}
Paul Yee's imaginary myth The Ghost Train mainly relates the experience of the heroin Choon-yi who is born with the drawing talent that helps those deceased Chinese labors return to China with the guidance of her father in her dream. On the road, she has confronted with many Chinese-Canadian cultural conflicts. Thus, the article will analyze the process of her emotional reconstruction from the aspects of her inner rebellion against the Canadian hegmonism, adaption and integration of the dual cultures, revealing how she accomplished a journey of salvation for nationalities and a pilgrim of seeking herself-growth.
\end{abstract}

Keywords: emotional reconstruction, rebellion, adaption, integration

\section{Introduction}

\subsection{Overview of the Author's Work}

Paul Yee, as a celebrated Chinese Canadian writer, was born in Spalding, Saskatchewan, and grew up in Vancouver's Chinatown. He was active as a volunteer for the Chinese Cultural Center and with the Chinese Canadian radio program Pender Guy. In 1996, he won the Governor General's Award and his books included Saltwater City: An Illustrated History of the Chinese in Vancouver, Teach Me to Fly, The Curses of Third Uncle, Tales from Gold Mountain and Ghost Train etc., all of which advocated the Chinese values and aimed at the construction of Chinese Canadian history. His works are children-centered, compounding the objective historical facts with the imaginary fairy tales, offering a novel view of the Chinese Canadian Literature in English. The Ghost Train is Paul Lee's magnums opus, which depicts a gifted girl named Choon-yi born with only one arm who can paint pictures looked as real as life went to Canada to take the soul of the deceased Chinese laborers back to their home under her father's guide and advice.

\subsection{Review of Previous Studies}

The data are mainly from CNKI, including 5 journals and 1 dissertation. From the perspective of time distribution, domestic scholars' research on The Ghost Train was mainly concentrated from 2008 to 2015, showing an upward trend. The research topics can be roughly divided into the following categories: firstly, the article Myth Archetype Theory and The Ghost Train (2007) written by Wen Jing, showed how the Chinese Canadian labors got their right of historical speech; secondly, from the aspect pf feminism, Chen Zhongming and Jia Hongbo's article "Teach Me to Fly": the Female literature and Cultural Study in Paul Yee's Works (2010), represented the new female image who continuously pursues her own independence and freedom to break the system of male supremacy; the next year, Yan Youping, Fu Jun wrote the article From the Historical Ghost Train (2012), indicating the opposite history and hegemony, appealing to fight for their own rights; and Liu Fang and Liu Yumei approached the issue of cultural identity, published the text The Combination of the Chinese and Western Culture-Analysis of the Image in The Ghost Train (2012), whose analysis of the character image, material image and scene image exhibited the sense of culture and historical significance, but have no further exploration of how the cultures combine and how to get rid of the differences in various ethnic groups. These researches have explored some themes of the novel, but are limited by the Canadian environment ignoring the China's condition at that time and the realistic life of Chinese. Therefore, the article will explore the heroine's emotional reconstruction combined with Chinese-Canadian cultures and experience to reveal the process of salvation for nationalities and a pilgrim of seeking growth under the influence of the dual cultures. 


\section{The Process of the Heroin's Emotional Reconstruction}

\subsection{Rebellion Against the Canadian Hegemonism}

According to the explanations of hegemonism in English-Chinese Dictionary, hegemonism means the oppression and discrimination existing in different nations, which is a kind of policy that the dominated country holds the tendency to invade, control and intervene in the affairs of other countries by its strong comprehensive national power. It's unveiled in the novel The Ghost Train through the perspective of the heroine Choon-yi. The period of Chinese first coming to Canada can be dated back the "Gold Rush" in the 1850s, nearly ten thousand Chinese taking part in the construction of the Pacific Railroad in Canada. When finishing the building of the railroad, almost all the Chinese are out of work, a few of whom choose to return to China and most of whom try to find jobs in Canada. While owning to the discrimination in Canada and the Chinese Exclusion Law of Canadian government in 1923 including the "Head Tax" and the poor and weak China having no status in the world. Particularly those unequal phenoms and unfair treatments to aliens make her bravely stand up to fight against Canadian hegemonism. From the history, it's known that they come to Canada for the "Gold Dreams" because of the poor condition, civil strife and bitter starvation and poverty-stricken in China. While when they come and live in Canada, their golden dreams vanish because of bitter and miserable life, as the author Hughes and Kallen points that they were hopelessly and helplessly pinned on the position of foreigner who would incur "decay and ruination" to "the new Canadian nation" (Hughes \& Kallen, 2011, p. 187), which indicates that they are regarded as strangers in this new land without any equal rights and any guarantee to their security, work and life etc., such as those deceased labors in Paul Yee's The Ghost Train, whose bitter experiences let Choon-yi in Canada view these unequal actions in the face directly and critically choose the life as her will and bravely rebel against hegemonism as a new generation to seek for her rights and voices.

Choon-yi born with drawing talents in a poor family learns her father and her nation's golden dream sailing to North America to make money for the sake of getting rid of poor-stricken life in Canada by building a railway through mountains. However, many of them has been dead in the process of building railway, which is known by her dream through her father's narration and suggestion that she should go to Canada with her drawings to bring those dead souls back to China because of the hegemonic Canadian policy setting limitations for the Chinese. Thus, she sets off to Canada with her ink brushes, colors and a roll of the finest paper as her father told her. During her journey to Canada, she overcomes all kinds of hardships such as the language differences, the unknown paths and people and the unclear fire-train her father described to her etc. The moment she arrives in Canada, she acquires others about her farther, but tragically she is told that her father has died, as the text reads, "She was told that her father had died. The side of the mountain collapsed and carried his crew into the river far below. No bodies were found." (The Ghost Train: 5). She feels heart ache, but she cannot believe in it. She continues to seek the train when her father coming into her dream again and showing her what the train is like. Under her father's guidance, Choon-yi finally succeeds in drawing the fire-train and seeing those deceased souls in the train, as the text writes, "Their clothing was torn and dirty, stained with mud and blood...As more and more men came aboard, they hailed each other with hearty welcomes." (The Ghost Train: 16), whose miserable sufferings and conditions in the drawing arouse so much grieve in Choon-yi's mind that she will do her best to bring those ghosts back to their home. She hears those Chinese labors' dreams and hope, "The men talked of their families, about how they longed to see them. They talked of hopes and dreams..." (The Ghost Train: 17), which makes her more brave and decisive to conquer any kind of difficulties and hiders to take them home, especially the hegemonism in Canada. Nothing can prevent her from the way to home and she succeeds in being the heroine of the nation. In particular, when facing hegemonism, she does not retreat and shrink from her responsibility of helping those Chinese souls rest in peace, growing up as a warrior to seek the identity and status of China, gradually understanding and fusing the Chinese and Canadian cultures together.

Accordingly, Choon-yi is the warrior in Paul Yee's pen, deified as the savior of the nation, carrying the author's emotion of rebellion against the hegemonism and hopes for the Chinese. She is brave enough to fight against those unequal regulations and gradually realizes the importance to be a strong girl to bring the people back to China, accomplishing the salvation of the nation and the emotional reconstruction of herself.

\subsection{Adaption to the Double Cultural Conflicts}

As a Chinese living in Canada, Choon-yi has witnessed the different cultures in her process of growing up. There are cultural conflicts between the dual cultures, such as the different religions, different dietary habits, various customs and beliefs. Facing with them, Choon-yi does not show much dissatisfaction and misunderstanding as she has when in the front of Canadian hegomonism. Instead, she adapts herself into the double cultures, combining them together and finding her own way to live. For instance, she accepts the Canadian education in 
the school, learning the knowledge and comprehending the culture. At home, her parents teach her how to behave and speak Chinese, and also to paint the drawings as she likes. Choon-yi is a talented girl in drawings and she grows happily under the love and protection of her parents. She gladly accepts the way of living and the habit of eating. She can feel the meaning of the different food, which should all be respected. She understands the idea of ghosts in China, on the other hand, she knows the power of science advocated in Canada. She gradually combines the differences with the similarities, living the life as she will.

For example, the idea of "Fallen leaves return to the roots.", is totally accepted by Choon-yi when she finds the deceased souls in the ghost train by her father's lead. At the outset, she shows a little unbelief because of the incredible dream that she has and also due to the different belief in Canada which she has been educated. Nevertheless, she draws the train as her father has told her. At the first sight of fire-train coming alive, she knows that her father's word is true. And she has to do what her father told her, that is to bring the Chinese souls back to China. Because the place is a temporary survival state and means for these Chinese who has lived in in order to make money for their family, whose decision to return to their native country would never be forgotten. It is at the moment that Choon-yi realizes the essence of Chinese idea. She accepts it and figures out the deep and profound sense of Chinese culture, adjusting to the background of times and environment. At the same time in the year of 1971, Canada has employed an open attitudes to those ethnic groups and they accept the different nations' cultures and values, which makes Choon-yi feel less confusion and doubt about the cultural conflicts and be the girl she wants. She is the heroine of Paul Yee's work The Ghost Train, and she carries the hope and the idea of the author. Therefore, the process of adapting to the cultural conflicts also and reflect the author's intention of the dual cultural combination and understanding. The self-growth of Choon-yi is the awareness of the whole nation's progress and prosperity.

The author Paul Yee invests Choon-yi with symbolic meaning as a heroine image conveying the theme of promoting Chinese values and accepting the good aspects of Canadian culture. As the myth shows, the experience of Choon-yi is undoubtedly a journey of salvation for nationalities and a pilgrim of seeking herself-growth, because she offers the hope for the elders and assists them to realize their dreams of coming back to China and on her road to Canada she goes through the tough difficulties and obstacles, which makes her become stronger and stronger to fight for her country and seek emotional reconstruction as a brave heroine in the heart of the nation.

\subsection{Integration of the Dual Cultural Values}

With the passage of time, Canada gradually encourages members of the different racial groups to share their language and culture, as Donna and Philip pose that Multiculturalism within Bilingual Framework was announced by Prime Minister Pierre Trudeau in 1971. Official federal policy views multiculturalism as "a powerful bonding agent" that "helps unite us and identify us, while at the same time allowing every element of our society to retain its own characteristics and cultural heritage" (Donna \& Philip, 1986), which shows the intention of promoting tolerance of diversity and integrating the cultural differences. Under the influence of the Canadian social factors, in addition to the element of China's growing powerful economy, Paul Yee foresees the hope and the trend of cultural combination. In the process of Choon-yi's growth, she combines the Chinese and Canadian cultures together, not just denying one or wholly affirming the other, but to seek for a more reasonable and suitable existence and get rid of the prejudices.

First of all, the integration of the dual cultures can be presented in the method of Choon-yi's memorial ceremony for those dead Chinese labors' souls. As the text reads, she is told by her father to light the sticks in the Chinese way to show her respect and pray for the deceased in order to bring them back to China, "At dusk, as the sun slips below the horizon, lay your painting open between the steel tracks. Light three big sticks of incense and plant them firmly..." (The Ghost Train, 12). Her behaviors show her exact understanding of the Chinese culture and the deep meaning behind it. And later in her dream under her father's guidance, when she sees the souls and hears their talking, getting a deeper understanding of their dreams and hopes that how they are eager to go home. Thus, she does the thing as her father said to take her drawing to China and "Then climb the highest hill in the region and burn it. Let our ashes sail on the four winds. That way our souls will finally find their way home." (The Ghost Train: 18), which is known as "the four winds", a kind of western sayings originated from the famous American poetry Shawondasee by Henry Wadsworth Long fellow "and the South-Wind over the prairie, wandered warm with sighs of passion" in order to peace the rest. The way she employs for the deceased shows that she and her father gradually gets the awareness of transforming their own culture and combining the dual cultures, further realizing the significance of the Chinese conception of "Fallen leaves have to come back to the roots", which is also the author's intention of seeking for equal development. Through the description of the heroine Choon-yi, the combination and integration of the dual cultures are represented in front of the readers. 
And the author's idea of returning to nation has been indicated in Choon-yi's words and behaviors.

In the fantastic myth, Paul Yee invents the gifted and heroic image Choon-yi through whom the author represents Chinese forms of mourning the dead by burning incense to worship the gods for the sake of having the souls in peace afterlife and also mentions the western ceremony in memory of the dead by letting the ashes sail on the four winds, which exhibits his positive attitude towards Chinese culture and objective perspective to view Canadian culture. It reflects that the Chinese has gradually integrated themselves into the dual cultures and found their status in the main society. Through the depiction of Choon-yi who carries the responsibility of the nation and the hope of the author, the spirit of Chinese and the identity reconstruction can be indicated.

\section{Conclusion}

The interpretation of the heroin's emotional reconstruction reveals how to live in the clash of dual cultures and how she has accomplished a journey of salvation for nationalities and a pilgrim of seeking herself-growth. The author Paul Yee boldly describes the fiction to reflect the reality and the dream to show the illusory death and life, indicating the historical truth and the serious sense of life. The depiction and narration of The Ghost Train are full of hope and harmonious developmental view based on the mutual understanding and cultural fusion.

\section{References}

Dong, Y., \& Liu, A. Q. (2013). Hybridity of Chinese Traditional Cultural Elements in Chinese Canadian works. Academic Exchanges, 235, 10-15.

Donna, \& Philip. (2002). Encyclopedia of Literature in Canada. Toronto: University of Toronto Press Incorporated.

Hughes, D., \& Evelyn, K. (1974). The Anatomy of Racism. Montreal: Harvest House.

Liu, F., \& Liu, Y. M. (2012). The Combination of the Chinese and Western Culture-Analysis of the Image in The Ghost Train. Masterpiece Appreciation.

Wen, J. (2007). Myth Archetype Theory and The Ghost Train. Journal of Harbin University.

Yee, P. (1996). The Ghost Train. Toronto: Ontario Arts Council.

\section{Copyrights}

Copyright for this article is retained by the author, with first publication rights granted to the journal.

This is an open-access article distributed under the terms and conditions of the Creative Commons Attribution license (http://creativecommons.org/licenses/by/4.0/). 